\title{
Islam and Politics in Mali: What Stakes?
}

\author{
Boubacar Samake \\ Central China Normal University, Wuhan, China \\ Email: samak.boubacar@yahoo.fr
}

How to cite this paper: Samake, B. (2019). Islam and Politics in Mali: What Stakes? Open Journal of Political Science, 9, 538548.

https://doi.org/10.4236/ojps.2019.93031

Received: June 10, 2019

Accepted: July 9, 2019

Published: July 12, 2019

Copyright (c) 2019 by author(s) and Scientific Research Publishing Inc. This work is licensed under the Creative Commons Attribution International License (CC BY 4.0).

http://creativecommons.org/licenses/by/4.0/

\begin{abstract}
The appearance of Islam in Mali dates from the thirteenth century (period of the empire of Mali). The main actors of this Islamization were the traders and the Almoravids. From this time to now Islam remains popular as well as its leaders. Religious leaders are the interface between public administration and society. Mali opted for democracy in 1991, which created more political openness, particularly in terms of public freedoms. Therefore, we are witnessing the rise of Muslim influence in the democratic game. This fact provokes the debate on the place of Islam in political life. The distinction between politics and religion is necessary, but it does not absolutely forbid Muslim actors from taking a democratic stand on issues relating to the life of the nation. The religious space is characterized by the multiplication of sects and the competition between its actors. This phenomenon is reinforced by the support of the powers of the Muslim world which are in logic of ideological competition. The security issue in Mali deteriorated by the terrorist attacks worries Mali and its Western partners. This fear is related to the will expressed by Muslim leaders displaying Islam as a source of social rules. Many observers believe that this will threaten the universal values of democracy.
\end{abstract}

\section{Keywords}

Islam, Politics, Stakes

\section{Introduction}

Mali is a secular country where believers of Islam, Christianity and traditional religions live peacefully. Behind unity in faith and the unifying and peaceful character of religion, some religious leaders engage in struggles for socio-economic and internal politics. They use religion to create competition between different brotherhoods or religious currents within Islam. People are trapped by these religious games. This antagonism between the different Muslim currents is often influenced by the exterior, especially the Gulf countries in Asia. Populations are 
one of the foundations of the polarization of interpersonal and intercommunity relations. Islam is the most popular religion and the most practiced in Mali. According to the 2009 census, there are $94.8 \%$ Muslims, $2.4 \%$ Christians and 2\% practicing the religion of our ancestors (animism) in Mali (Fourth General Population and Housing Census of Mali GPHC, 2011). The religious factor occupies a very important place in Malian society. This gives the religious authorities a moral and social responsibility. This reality reveals the weakening and the contestation of the State, of the political class since the political and security crisis of 2012. When armed groups of the north claiming the application of the Islamic law (sharia) attacked the country, the Political decision-makers and actors lacked adequate political vision and arguments, dissuading or forcing rebels and their terrorist accomplices to abandon their plans. The socio-economic, political, moral and security bankruptcy of the State of Mali gives Muslim leaders considerable weight in public and political life.

This work analyzes the involvement of the religious in the political sphere in Mali. We analyze the issue of religious influence on the Malian political system. The lack of regulation of the religious framework is a threat to political and social stability. The fundamental question is: are Islam and politics compatible in a context marked by terrorism in favor of the socio-political stability of the populations? Indeed, our work revolves around: 1) The history of Islam in Mali; 2) Islam and democracy; 3) The multiplication of Islamic sects; 4) Competition within Islam and foreign influences; 5) Islam and terrorism issue; 6) Islam factor of social peace; finally the conclusion.

\section{The History of Islam in Mali}

The Empire of Ghana in 1076 was invaded by the Berber almoravids that forced a part of the population to convert to Islam. This religion was disseminated by the political and commercial elites and also occupied an important place in the great precolonial empires (International Crisis Group, 2017). From then until the eighteenth century "court Islam" remained an affair of elites. During this century, Islam became a popular religion led by spiritual leaders: Islam confraternities. Confraternities are communities of faithful or followers grouped around charismatic leaders. The brotherhood will become more and more popular and a coveted phenomenon of Muslim believers in Mali, Senegal, Mauritania and Guinea. It thus creates a specific mode of organization; each spiritual master gathers and animates a community of faithful. Indeed, between the marabout and his disciples there is a relationship of dependence. This relationship is evident in the absolute submission of the disciple to his spiritual master. This situation also gives religious leaders considerable power. The appearance of brotherhoods and the development of their mode of organization are contemporaneous with the colonization to which the local populations find distinct forms of resistance.

However, the Islam of the brotherhoods will be a decisive step which marks the accession of the latter in the political field. Spiritual masters like Samory 
Toure, El hajj Omar Tall and Cheick Hamala will each lead a resistance against the colonial army. The colonial administration uses pragmatic strategies that lead to a beneficial collaboration with religious leaders to achieve its goal of domination. If the colonial power had established an effective authority in urban areas, it also needed the support of influential religious leaders in rural areas to legitimize its authority. Religious leaders served as local relays. In return, religious leaders benefited from political power and significant economic benefits. The spiritual leaders had great authority over a large part of the population and enjoyed everywhere great moral and social prestige. The colonial authorities absolutely controlled the State apparatus.

The accession to power of the socialist Modibo Keita in 1960 constitutes a major political turning point. When the new State of Mali is built and the constitution States that "the Republic of Mali is secular", the new rulers know that they must rely on religious leaders for social stability. These are called to ensure a substantial double function in the political system. That means the legitimation and intermediation with local populations. The important role of the Imams in Malian political life will be noticed under the political regime of Moussa Traore especially with the structural adjustment program of the Bretton Woods institutions in 1980.

The fall of the Moussa Traore regime in March 1991, the introduction of the multiparty system resulting from the constitutional reform of 1992, will continue to place the Imams in the position of referee constantly solicited in the management of public affairs and during elections. Through voting instructions, they are often considered as "kingmaker". Some Imams have kept a duty of reserve and impartiality while others have preferred to be influential in the political sphere (Fousseyni, 2012).

\section{Islam and Democracy}

Democratization movement in Africa in the early 1990s has yielded mixed results regarding the creation of a real democracy. But the movement has nevertheless contributed to significant liberalization and respect for democratic principles such as freedom of association across the continent. Beyond the classic forms of expression in "civil society", the rapid development of new social organizations has continued into the religious sphere.

In many countries of Muslim Africa, this has fostered the emergence of an "Islamic public sphere" and the development of what we may call an "Islamic civil society" (Holder, 2009). The multiplication of varied religious voices has in some cases reflected the debates between Sufism and its detractors. It has also led to new dynamics and even a "democratization" of religion itself, in that it has created new opportunities for individual voices to challenge established authorities (Tayob, 2007).

Political democratization has put political issues on the public agenda. As a result, debates on the appropriate position of Islam in relation to certain issues 
led to fundamental interpretation, and thus provided the opportunity for religious change motivated by these public discussions.

In the Sahelian countries like Mali, this process has given rise to broad debates on political issues, but few fundamental conflicts over religion (Villalón, 2010). Religious voices have been loudly heard in the political arena, but without calling into question the principle of secularism. A significant number of countries in French-speaking Africa have paved the way for democratization in the 1990s through "national conferences". These conferences were convened to chart a transition path towards the inauguration of the new regimes. In the Muslim Sahel, the two most important countries that have followed this path are Mali and Niger. The overthrow of the military regime in Mali and the deterioration of the political situation in Niger in 1991 led to transitional governments, elections and the inauguration of new regimes. Although the Malian democratic experience was widely regarded as a major success for twenty years, the experience of Niger was much more difficult and marked by various constraints. In both countries, however, there has been a real and substantial liberalization of political life and an ongoing commitment to the democratic system. Two aspects of the democratization process in the French-speaking Sahel are essential for understanding the evolution of Muslim politics in these countries.

First, the pro-democracy movements then fueled by popular frustration and economic grievances, were led by the educated little elite who received a formal education in French: "intellectual" Francophones. For example, students, teachers, lawyers, journalists and human rights activists were among those most responsible for leading the new "civil society" to demand change. In the international enthusiasm for just democracy at the end of the Cold War, there were external support movements for these groups, strengthening their positions. Then, the civil society actors who defend democratic values were inspired to design new regimes of the model they knew best, namely the Fifth French Republic. Their fundamentally normative approach to the democracy they sought to build, suggested the need to focus on social transformation to transform cultures that are compatible with their vision of democracy, rather than to develop institutions where would focus on local values. This approach quickly contributed to clashes with representatives of Muslim groups. In Mali and Niger, an ideologically and religiously diverse picture of new Muslim associations was quickly formed and officially recognized. There were periods of rivalry and occasional conflicts between the different brotherhoods of Islam, but they soon learned to unite in opposition to certain democratic values that contradicted certain Islamic values. These contradictions or manifestations between Muslim groups and governments around moral and social issues are as substantive as they are symbolic, such as holding fashion shows or opening bars during Ramadan. These conflicts were often framed in the criticism of the notion of democracy by religious groups. The most important feature of political Islam in Mali is the fact that religious society quickly came not only to accept the idea of democratization, but also to learn to play the democratic game to guide it to their advantage. 
In recent years the Malian political debate has focused on the introduction or the growing influence of Muslim leaders in the political field. These political exchanges that are widely practiced within the Muslim community shake Malian society. This is the debate on the death penalty, the status of women in society, excision, homosexuality, corruption, youth unemployment. An important element of the debate is the rise of Muslim intellectuals, often organized in associations (Sabati 2012), who share a commitment to democracy and willingness to engage in public political debate. These Muslim intellectuals also argue that in a democracy, political issues should reflect popular (religious) feeling.

The population of Mali is mostly composed of Muslims. Thus, very popular Islam is a refuge, a bulwark of social disparities, and the injustice that is normally the responsibility of the public authorities. The events of March 22, 2012 caused the fall of President Amadou Toumani Toure. They were also revealing of the deficiencies of the political class of Mali, which pushed people to appeal to religious leaders. The political class very discredited because of his attitude towards the people and the latter finally turned to religious leaders (Muslims) then considered as the true opinion leaders. Politicians are seen by the people as incompetent and corrupt officials. Some religious leaders including Imam Mahamoud Dicko and Cherif Ousmane Madani Haidara have combined political and religious discourse to win the trust of the people. This people (illiterate majority) ignore issues related to international political contexts that have a serious impact on national politics. As an illustration on April 5, 2019 Imam Dicko with extraordinary mobilization capacity organized a protest march to demand the resignation of Prime Minister Boubeye Maiga. A remarkable crowd gathered in the streets of Bamako brandishing slogans hostile to the institutions of the republic and partners committed to the stabilization of the country. This so-called peaceful march has greatly worried the Malian authorities. Following this popular demonstration, the former will resign the government he led. This situation sufficiently proves the weight of religion in a political environment. The fundamental reason for the rise of political Islam in Mali is due to the behavior of politicians have taken control of institutions to enrich themselves illegally that is why they suffer from legitimacy. The bearers of the public authorities in Mali are the epitome of bad governance, corruption of favoritism...

Since the power of the majority is the essence of democracy, the term Islamization of democracy is the approach in which some Muslim leaders have enrolled. However, the constitution of Mali of 1992 formally prohibits the creation of religious political parties. The religious phenomenon, however, did not remain outside politics and especially creates new types of relations between the Islamic world and the State with increasing tensions between Muslim brotherhoods. In 2012 several armed movements took control of the northern region and recently a part of central Mali (Mopti and Segou). These armed groups claim the establishment of an Islamic State and the application of sharia law. The current events have revealed a new dynamic in Malian politics, exploited by political elites, with Muslim leaders becoming valuable political partners (Isbell \& Haidara, 2018). 
This situation encourages the multiplication of Muslim associations with the aim of entering the political arena.

\section{The Multiplication of Islamic Sects}

Mali, with more than $90 \%$ Muslims, is a secular country where the practitioners of Islam, Christianity and traditional religions coexist peacefully. If conflicts between religions remain marginal, the existence within Islam, the majority religion, of strife affecting social cohesion has become a national concern. These cleavages are carried by the different currents within Islam and their instrumentalization. One of the main threats to national cohesion is the multiplication and increased competition between currents within the large Islamic family in Mali. Given the central unifying role of religions in Mali, the tearing of communities between them is a risk to the major potential consequences for social cohesion. The multiplication of currents within Islam and the difficulties associated with the regulation of this sector pose a threat to peace and cohesion. The first sign of religious conflict is the creation of mosques in all the alleys in Bamako and the interior of the country. This proliferation of new mosques throughout Mali induces according to many observers a diversification of the interpretations of the Holy Quran which, for many people, is harmful because it can lead to a social division.

The diversification of sects and mosques is not a problem in itself, but it is advantageous to compete among the leaders of these currents that are problematic. In Saudi Arabia, which is the reference of the Muslim world, in every street one can notice a mosque, but this has not caused any problems between them. Thus, the diversification of sects is only an illustration of the intense competition of local, national and foreign actors on the field of religion, which is problematic. On the national level, this competition leads to a fairly chaotic situation in the religious leadership. The representativeness of religious leaders is thus often challenged by a fraction of the community, while Muslim associations emerge from everywhere: Mali now has more than 180 registered Islamic associations, grouped in various coordination's including the Malian Association for Unity and Progress of Islam (MAUPI), the League of Imams (LIMAMA), the League of Preachers, the National Union of Muslim Women (NUMW), the Malian Youth Association Muslims (MYAM). Like the policies and those of the emerging civil society, for the Islamic actors, it is a question of constituting a new social force. In this perspective of constitution of Islamic civil society, there has been for some years a gradual transfer of intellectuals, political actors and officials to the political sphere (Doquet, 2007). This trend is reinforced by government initiatives providing financial support to Muslim associations. This action by public authorities facilitates the rallying of Muslim organizations creating a new religious modernity that articulates faith, public morality and rationalization. Thus Mali will know the creation of Non-Governmental Organizations with Islamic vocation and charity. These NGOs are in the wake of the Interna- 
tional Organizations of Golf Countries (Wamy, Al Muutada), Pakistan (Humanity First), and Great Britain (Islamic Relief). The objective of these NGOs revolves around re-Islamization, teaching and social mediation.

Once again, multiplication does not pose a problem as much as competition between these organizations. Or a long time, the conflicts between the different believers and provocative and sometimes even within the same course are common. The situation has evolved rapidly into a hardening of positions, so that more speech by the voice currents is seen as a challenge to other current, or more directly to other voice. According to some, the tension is maintained by the financial support of foreign religious organizations, both public and private. Well before the beginning of 2012 crisis, this competition between believers was brilliant and could even be used by armed groups or criminal groups. These groups, whose real objectives have very little to do with Islam, have contributed to the instrumentalization of religious discourse in order to give an appearance of legitimacy to their action and to facilitate their operations of recruiting candidates for jihad. According to a national of GAO speaking to Radio France International about the occupation of his city by the Salafists Tuareg and allies says "those who came to submit to their barbarism in the name of Islam are not Muslims, we are Muslims from our ancestors, their goals were to occupy the ground to better do their dirty business. Otherwise, we know the Koran better than they, those who followed them, understood and are coming back, they all regret today. The risks on social cohesion associated with these increasingly cumbersome foreign interventions also seem to be shared at different levels of the state. This surge of tensions continues and intensifies, despite a number of government initiatives over the last 20 years aimed at making the issue stable in view of the risks posed to social cohesion. While for some observers such initiatives are as devious to the principle of secularism, they nevertheless recognize that they are necessary in the present context. Among the measures adopted, include the establishment of a High Islamic Council of Mali (HIC), which must serve as a single interlocutor for the Malian government and in which all the main Muslim tendencies are found.

\section{Competition within Islam and Foreign Influences}

In parallel with this competition at local and national level, for several decades in Mali, traditional Islam is strongly competed by new currents, considered "foreigners" or "reformers". By taking the genesis of the Muslim religion in Mali, there was only Sufism, inside which were the Tidiania, the Oumaria, and the all-embracing and peaceful Islam. One of the factors that explain this harsh competition between currents within Islam is attributed to external influences. The great ideological competition of some Middle Eastern and Maghreb States promotes the multiplication of religious sects throughout the world. Mali has become a privileged field in relation to the low regulation of the religious scene by the State and religious leaders (Loi No61-86/AN-RM du 21 Juillet, 1961). Holding large financial resources, these countries are investing heavily in the 
construction of places of worship (mosques) and religious teaching at the end of capturing the faithful to propagate their ideology. The openness to Arab and Asian countries has allowed the formation of many young people in the field of Islamic religious education to countries such as Egypt, Iran, Iraq, Morocco, Saudi Arabia, Qatar, Libya, etc. Upon their return, the students come back with the ideologies associated with the various currents with its corollary of various interpretations of the Koran and hadiths and of course with money to impose their perceptions. All this combined with corruption means that Muslims cannot get along. In this context there appears a radical Islam in the north of Mali.

The establishment of democracy has fostered freedom of association; it has above all affirmed the secularism and the republican form of the State. This means that there can be no Religion State in Mali. Yet, from the denominational sphere, Islam has slowly introduced itself into the political space. Indeed the Malian constitution formally forbids the creation of any political party based on religious feature. But still we can observe the evolution of religious movement in political realm. The Malian Islamic associations have imposed themselves in the political public space while providing other ideas. They hinder the secular provisions of the Republic of Mali by supporting a particular political party. In Mali "Islam", which has become a popular religion, is now used by political actors to get the power.

The transnational nature of terrorism, the radicalization of religious speech and the weakness of the Malian State make the country vulnerable to terrorism activities.

\section{Islam and Terrorism Issue}

The terrorist attacks of September 11, 2011 in the United States have provoked many indignations and national questions about Islam. Many reflections on the role of Islam in the democratic system have been realized. In several countries, this issue has led to a revision of certain historical religious positions and the emergence of new perspectives (Villalón, 2015).

The developments since 2009 in the Islamic debate in Mali have changed the stakes of the religious question and its practice both in everyday life and in politics. The Malian society, on the religious level, has revealed two main forms of evolution, the main purpose of these developments being the re-Islamization of society. They result in the rise of armed extremism and non-violent religious conservatism. These dynamics have therefore been expressed in two facets, and in different geographical areas.

January 17, 2012 marks the fall of Mali in a series of crises. Started by the Tuareg rebellion in the north, on March 22, 2012, political and institutional unrest in the south increased, leading to the overthrow of President Amadou Toumani Toure (elected in 2002). This general crisis situation resulted in the occupation of the entire north of the country (65\% of the national territory for only $10 \%$ of the population) by armed groups acting in the name of Islam. This is Al-Qaeda in the Islamic Maghreb (AQIM), the Movement for Unity and Jihad in 
West Africa (MOJWA) and Ansar Ed Dine (Haidara, 2015).

The crisis in Northern Mali has shown two totally opposite views of Islam. What is called "Malian Islam" has the particularity of being tolerant is in front of Salafist Islam, violent, which has imposed itself by the arms. We clearly distinguish what we have called "Malian Islam" from jihadist Islam. But within the whole that forms the Malian Islam, there is also a struggle of ideologies and a deep division. Part of the faction of "Malian Islam" is getting closer to the Salafists of North-Mali.

The international intervention led by France to Mali in 2013 helps disperse Islamists in the north of the country without being able to neutralize them absolutely. In this context, two dynamics appeared. First, terrorist groups have failed to establish a consistent base to support their religious propaganda. Foreign forces will prevent the implementation of this religious program. Then the international community aware of the capacity of nuisance Islamists has written its struggle in the long term. In particular, armed groups have had time to organize themselves to carry out targeted attacks. It is important to point out that the intervention of foreign forces in Mali has been hailed and approved by all Muslim brotherhoods in Mali. The tendency of the reformers suspected of complicity with the Islamists approved the intervention. Despite many years of war to neutralize terrorists, security remains a concern in Mali. This crisis has clearly provoked debates and revived contradictions that may have implications for Islamic ideologies and intercommunal relations in Mali. The discussions naturally relate to the positions that other Muslims must have with respect to the Sharia-seeking terrorist movements. These very sensitive debates animate the Malian religious space. The question is whether or not to negotiate with the terrorist movements? On the question the opinions diverge. This issue was the source of tension in the Muslim milieu which has within it several trends in Islam. On the one hand, the powerful Sunni Imam Mahamoud Dicko offered his services as an interlocutor to negotiate with the Islamists. On the other hand, the leader of a large Islamic organization (adept of tolerant Islam) Cherif O Madani Haidara was not in favor of this initiative by Imam Dicko. The very popular Cherif O Madani Haidara wanted the use of force to neutralize armed bandits. The majority of Malian public opinion adhered to this Haidara initiative. Finally, Dicko's mediation will not go far.

The establishment of the government in 2013 after the troubled times clearly indicates the return to the effort to build a democratic system in a secular state respectful of religious beliefs.

\section{Islam Factor of Social Peace}

Through the content analyses carried out during this work, we believe that the reconstruction of the State in Mali remains an important stake to reinforce democracy and social cohesion. A determining element of this reconstruction is the redefinition of the relationship between politics and religion. Because of the social and spiritual diversity in Mali, it seems necessary to determine the field of 
intervention of the religious. Many outside observers analyze the religious involvement in politics under the dimension of secularism. This approach is not unanimous among the entire population who believe that the religious must be neutral, serve as conciliator in case of problem between communities.

Some scholars also do not perceive the interpenetration between politics and religion as a political risk but rather a threat to the preservation of social cohesion. Although democracy offers civil rights to all citizens, the sensitivity of religion requires some clarification of the roles assigned to social actors. Finding a well-defined framework for (Muslim) religious especially in the face of a weak State is a considerable challenge. This reorganization of the religious field must nevertheless take into consideration the social and spiritual realities ( $92 \%$ of the Malians are Muslims). Because of the weaknesses and limits of power, it seems useful to involve Muslim leaders in this perspective in order to make consensual decisions to properly identify and organize the field of religion in a democratic Mali. This approach can be a way for the public power to have absolute control over religious activities, especially in a global context marked by crises (terrorism and violent extremism). For these reasons, the Malian authorities in collaboration with the spiritual leaders must combine efforts to convince Muslim co-religionists to observe measures of tolerance in favor of national stability.

\section{Conclusion}

Religion occupies a very important place in Mali. It is the main cement of the social fabric. The actors of the religious movement keep the consideration and the respect of the populations. Some fellow citizens are even reluctant to ask for the role that they can play in the political field. This question is very sensitive nevertheless it must be well treated for the well-being of the population. In Mali, no one questions the unifying nature of religion, but the manipulation of sects within Islam by some of its leaders to profit is a major risk for unity and national cohesion. Religious leaders have moral and social authority, which is why they are influential. However, we ask the question of whether Islam and politics are separable?

\section{Conflicts of Interest}

The author declares no conflicts of interest regarding the publication of this paper.

\section{References}

Doquet, A. (2007). Des sciences humaines à l'islam. Une voie de la recherche Malienne. Cahiers D'études Africaines, 2, 371-389. https://doi.org/10.4000/etudesafricaines.7373

Fourth General Population and Housing Census of Mali GPHC (2011). State and Structure of Population (p. 74). National Institut of Statistic.

Fousseyni, T. (2012). La montée du religieux musulman dans le jeu politique actuel du Mali, université de Bamako. 
Haidara, B. (2015). Les formes d'articulation de l'islam et de la politique au Mali. These de Doctorat, École Doctorale Montaigne Humanités (ED 480).

Holder, G. (2009). L'islam, nouvel espace public en Afrique (p. 14). Paris: Karthala.

International Crisis Group (2017). Islam et politique au Mali: Entre réalité et fiction.

Isbell, T., \& Haidara, F. (2018). Les Maliens sont divisés sur le rôle de l'islam et pensent que les politiciens se servent de la religion pour régner (p. 1). Afrobaromètre.

Loi No61-86/AN-RM du 21 Juillet (1961). Relative à l'organisation de la liberté religieuse et de l'exercice des cultes.

Tayob, A. (2007). Muslim Publics: Contents and Discontents. Journal for Islamic Studies, 27, 1-15. https://doi.org/10.4314/jis.v27i1.39928

Villalón, L. A. (2010). From Argument to Negotiation: Constructing Democracies in Muslim West Africa. Comparative Politics, 42, 375-393.

https://doi.org/10.5129/001041510X12911363509954

Villalón, L. A. (2015). Islam et politique à l'ère de la démocratie et du terrorisme (pp. 147-148). Ed itinéraires ouest-africains. 